\title{
Aktivitas Air (Aw) dan Warna Dendeng Daging Giling Terkait Cara Pencucian (Leaching) dan Jenis Daging yang Berbeda
}

\author{
Water Activity (Aw) and Colour of Dendeng Giling (from minced meat) \\ as Affected by Leaching Method and Kind of Meat \\ Suharyanto \\ Jurusan Peternakan, Fakultas Pertanian, Universitas Bengkulu \\ Jl. Raya Kandang Limun, Bengkulu. 38123 \\ Telp 073621170 ext 206. e-mail: suharyanto@unib.ac.id
}

\begin{abstract}
Dendeng is a typical Indonesian jerked meat product commonly made from sliced or ground beef with $2 \mathrm{~mm}$ thickness. This research was conducted to study the effect of leaching methods and kinds of meat on water activity ( $\mathrm{Aw}$ ) and color of dendeng giling (from minced meat). The experimental design used a completely randomized factorial design $(3 \times 3)$ with three replications. The first factor was leaching method with 3 levels (no washing, washed in $1.5 \times 1.5 \times 1.5 \mathrm{~cm}$ sizes and washed in minced meat). The second factor was kinds of meat: Horse, Lamb and Beef. The results of this research indicated that leaching method increased the lightness and yellowness $(\mathrm{P}<0.05)$ of dendeng, and there was no interaction between leaching methods and kind of meat. Neither leaching methods nor kinds of meat affected on water activity of dendeng $(\mathrm{P}>0.05)$.
\end{abstract}

Keywords: dendeng, water activity, meat color.

\begin{abstract}
ABSTRAK
Penelitian ini dilakukan untuk mengkaji pengaruh cara pencucian (leaching) dan jenis daging terhadap nilai aktivitas air (Aw) dan warna objektif dendeng daging giling. Rancangan penelitian yang digunakan adalah Rancangan Acak Lengkap berfaktor $(3 \times 3)$ dengan tiga ulangan. Faktor pertama adalah pencucian dengan tiga taraf (tanpa pencucian, pencucian pada ukuran 1,5 x 1,5 x 1,5 cm dan pencucian pada daging giling). Faktor kedua adalah jenis daging: kuda, domba dan sapi. Hasil penelitian ini menunjukkan bahwa cara pencucian meningkatkan derajat kecerahan dan kekuningan $(\mathrm{P}<0,05)$, dan tidak ada interaksi antara cara pencucian dan jenis daging. Kedua faktor tersebut tidak berpengaruh terhadap aktivitas air dendeng $(\mathrm{P}>0,05)$.
\end{abstract}

Kata kunci : dendeng, aktivitas air, warna daging.

\section{PENDAHULUAN}

Penelitian dan pelaporan terkait dengan aplikasi teknologi surimi untuk bahan daging non ikan sudah mulai banyak dilakukan untuk menelaah pengaruhnya pada produk basah dan semi basah seperti sosis, bakso dan dendeng (Mega, 2006a, 2006b, Suryaningsih, 2006 dan Suharyanto et al., 2008). Surimi itu sendiri merupakan produk antara pengolahan daging ikan yang digiling kemudian dicuci (leaching) dengan air dingin hingga beberapa kali dan kemudian dipress. Hasil setelah dipres ini kemudian menjadi bahan baku bagi pembuatan produk-produk lanjutan seperti sosis dan bakso.

Proses pencucian pada pembuatan surimi dimaksudkan untuk memisahkan 
daging dari bahan yang larut dalam air, lemak, darah (pigmen-pigmen) dan untuk memperbaiki flavor dan warna serta meningkatkan kekuatan gel (Toyoda et al. 1992). Melalui pencucian, produk-produk olahan semisal bakso dan sosis diharapkan memiliki kekuatan gel yang baik disertai dengan flavor dan warna yang menarik bagi konsumen. Teknologi inilah yang kemudian dicobakan kepada daging non ikan seperti daging domba yang diketahui memiliki flavor kurang disukai dan daging kuda yang selain flavornya kurang disukai juga memiliki warna yang relatif gelap. Menurut Mega (2006b), pencucian berpengaruh terhadap aroma, warna dan teksur nikumi dan mampu meningkatkan kesukaan konsumen terhadap aroma, warna dan teksur nikumi (surimi-like material).

Penelitian terkait surimi dan surimi-like lebih banyak mengkaji pencucian dan krioprotektan (Nowsad et al., 2000), frekuensi pencucian (Mega, 2006a), dan frekuensi pencucian dan $\mathrm{pH}$ (Jin et al., 2007, 2008 dan 2009). Kajian terhadap ukuran partikel daging saat dicuci belum dikaji. Oleh karena itu, penelitian ini mengkaji aplikasi leaching (pencucian) pada ukuran partikel daging yang berbeda untuk pembuatan dendeng. Dendeng bisa dibuat dari berbagai macam jenis daging, termasuk daging kuda dan domba. Penelitian ini mengevaluasi pengaruh cara pencucian dan jenis daging terhadap aktivitas air (Aw) dan warna objektif dendeng daging giling.

\section{MATERI DAN METODE}

Penelitian ini menggunakan Rancangan Acak Lengkap (RAL) pola faktorial ( $3 \times 3$ ) dengan 3 ulangan. Faktor pertama adalah pencucian (leaching), yaitu tidak dicuci dan daging langsung digiling (L0), dicuci pada kondisi dicacah dengan ukuran sekitar $1,5 \times 1,5 \times 1,5 \mathrm{~cm}$ kemudian digiling (L1) dan dicuci setelah digiling (L2). Faktor kedua adalah jenis daging, yaitu daging kuda (DK), daging domba (DD) dan daging sapi (DS).

Bahan utama yang digunakan pada penelitian ini adalah daging kuda, domba dan sapi bagian paha (topside dan silverside). Daging kuda diperoleh dari pasar Ciroyom Bandung dan daging domba dan sapi diperoleh dari pasar Anyer Bogor. Daging yang diperoleh ini berumur 12 jam posmortem dan kemudian disimpan dalam termos pendingin untuk kemudian dibawa ke laboratorium dan disimpan beku hingga digunakan penelitian. Thawing dilakukan dengan menggunakan air mengalir suhu kamar.

Daging yang telah diperoleh kemudian dipisahkan dari lemak dan jaringan ikat dan kemudian dikelompokkan berdasarkan perlakuan. Pencucian dilakukan satu kali dengan menggunakan air dingin bersuhu $5-10{ }^{\circ} \mathrm{C}$ dengan perbandingan air dengan daging sebesar 3:1. Setelah dicuci, daging diperas dengan menggunakan kain kasa. Kemudian daging yang telah digiling dan dicuci sesuai perlakuan, dicampurkan dengan garam sendawa $(0,3 \%$ dari berat daging giling yang siap dibuat dendeng) dan diperam (curing) semalam. Setelah curing maka ditambahkan bahan-bahan yaitu, garam (3\%), gula putih $(15 \%)$, ketumbar $(2,5 \%)$, bawang putih $(1,5 \%)$, lengkuas $(0,3 \%)$, merica $(0,3 \%)$ dan asam jawa $(0,1 \%)$ yang dihitung berdasarkan berat daging giling yang akan dibuat dendeng. Alur proses pembuatan dendeng giling pada penelitian ini dapat dilihat pada gambar 1.

Variabel yang diamati pada penelitian ini adalah (a) aktivitas air (Aw) yang diukur dengan menggunakan alat pengukur Aw meter. Sebelum melakukan pengukuran, alat ini dikalibrasi dengan larutan $\mathrm{NaCl}$ yang memiliki nilai 


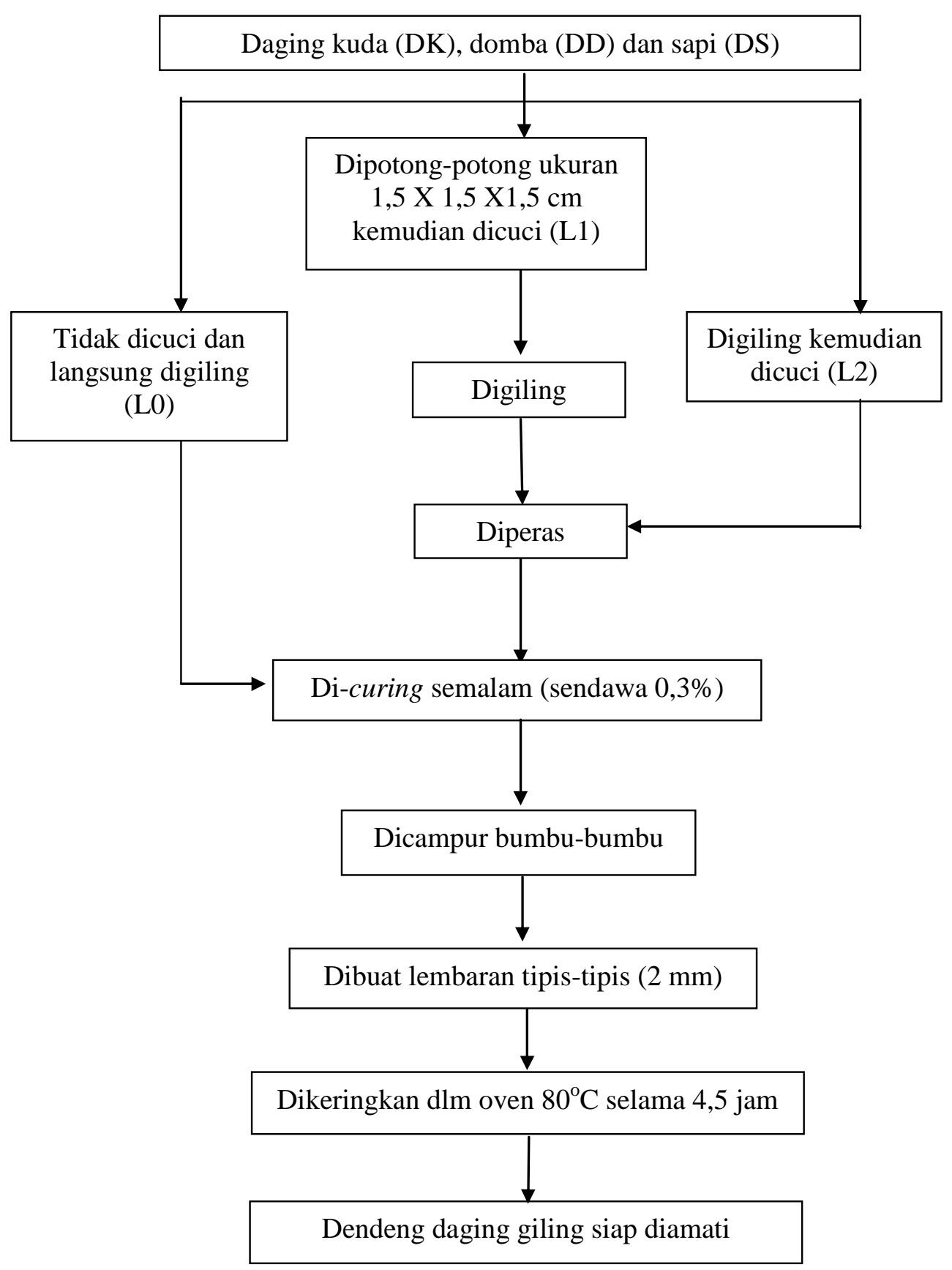

Gambar 1. Skema alur pembuatan dendeng daging giling penelitian

Aw sekitar 0,75. Setelah itu, sampel diletakkan ke dalam Aw meter dan bila sudah dalam posisi ready, lalu tekan tombol start. Maka kemudian nilai Aw akan terbaca bila alat tersebut dalam posisi completed. (b) Penilaian warna dilakukan dengan menggunakan Chromameter. Pengukuran ini dilakukan dengan cara menyinarkan alat ke permukaan sampel. Hasil peyinaran dari alat ini menunjukkan derajat "kecerahan", "kemerahan" dan "kekuningan" yang masing-masing 
dicerminkan oleh nilai " $L$ ", "a", dan " $b$ ". Nilai "L" menunjukkan derajat kecerahan yang nilainya berkisar antara 0-100 dimana nilai 0 menunjukkan warna hitam, nilai 100 menunjukkan warna putih. Nilai "a" menggambarkan derajat kemerahan dan kehijauan yang nilainya berkisar antara -80 sampai 100. Nilai "a" negatif menunjukkan bahan berwarna hijau dan bila positif menunjukkan berwarna merah. Nilai " $b$ " menunjukkan tingkat kekuningan dan kebiruan dengan kisaran nilai -70 sampai +70 . Nilai " $b$ " negatif menunjukkan warna kuning dan bila positif menunjukkan warna biru.

Data yang diperoleh diuji dengan analisis keragaman menggunakan software SPSS 11 for windows dan apabila terdapat perbedaan nyata dengan selang kepercayaan 95\% akan diuji lanjut dengan Duncan's New Multiple Range Test.

\section{HASIL DAN PEMBAHASAN}

\section{Aktivitas Air}

Aktivitas air (Aw) menggambarkan banyaknya air bebas pada daging yang dapat digunakan untuk aktivitas biologis mikroorganisma. Oleh karenanya nilai Aw berkaitan dengan tingkat keawetan suatu bahan pangan.

Hasil penelitian ini memperlihatkan bahwa nilai Aw dendeng memiliki kisaran rata-rata antara $0,71-0,77$ dengan rataan umumnya 0,75 (Tabel 1). Hasil analisis ragam menunjukkan bahwa Aw dendeng tidak dipengaruhi oleh faktor pencucian, jenis daging dan interaksi antara keduanya $(\mathrm{P}>0,05)$. Bila ditinjau dari faktor pencucian, rataan nilai $A w$ dendeng untuk L0, L1 dan L2 masing-masing adalah 0,75, 0,76 dan 0,76 . Sedangkan menurut faktor jenis daging maka rataan nilai Aw untuk dendeng daging kuda, domba dan sapi masing-masing adalah 0,74, 0,75 dan 0,77.

Nilai Aw hasil penelitian ini ternyata masih lebih tinggi dari pada Aw dendeng pada umumnya. Tingginya nilai Aw pada penelitian ini mungkin disebabkan oleh kelembaban lingkungan yang cukup tinggi sehingga ketika dendeng dikeluarkan dari alat pengering maka terjadi proses menuju keseimbangan kandungan air dari udara dan dendeng dengan cara menyerap air dari udara. Hal ini menyebabkan Aw dendeng menjadi tinggi. Hubungan antara Aw dengan kelembaban adalah hubungan kesetimbangan antara kandungan air bebas di suatu bahan dengan kandungan air di udara. Bila kadar air udara tinggi maka bahan akan menyerap air udara dan sebaliknya bila kadar air bebas pada bahan lebih tinggi dari pada di udara maka udara akan menyerap air bahan hingga dicapai suatu keadaan kesetimbangan.

Namun demikian Aw ini masih termasuk dalam kisaran Aw bahan makanan semi basah, yaitu 0,60-0,92. Sedangkan menurut Salguero et al. (1994) bahwa bahan pangan semi basah memiliki Aw antara 0,60-0,91 dan menurut Purnomo (1996) bahwa dendeng memiliki Aw 0,60-

Tabel 1. Nilai aktivitas air (Aw) dendeng

\begin{tabular}{|c|c|c|c|c|c|}
\hline Variabel & Jenis Daging & L0 & L1 & L2 & Rataan \\
\hline \multirow{4}{*}{$\begin{array}{l}\text { Aktivitas } \\
\text { Air (Aw) }\end{array}$} & Kuda (DK) & $0,71 \pm 0,005$ & $0,76 \pm 0,006$ & $0,75 \pm 0,005$ & $\mathbf{0 , 7 4} \pm 0,005$ \\
\hline & Domba (DD) & $0,75 \pm 0,005$ & $0,75 \pm 0,005$ & $0,76 \pm 0,004$ & $\mathbf{0 , 7 5} \pm 0,005$ \\
\hline & Sapi (DS) & $0,77 \pm 0,003$ & $0,77 \pm 0,004$ & $0,77 \pm 0,004$ & $\mathbf{0 , 7 7 \pm 0 , 0 0 4}$ \\
\hline & Rataan & $0,75 \pm 0,004$ & $0,76 \pm 0,005$ & $0,76 \pm 0,004$ & $\mathbf{0 , 7 5} \pm 0,004$ \\
\hline
\end{tabular}

Keterangan: Angka yang dikuti superskrip berbeda pada baris atau kolom yang sama menunjukkan perbedaan nyata $(\mathrm{P}<0,01)$. $\mathrm{L} 0=$ tanpa pencucian; $\mathrm{L} 1=$ daging dipotong berukuran $1,5 \times 1,5 \times 1,5$ $\mathrm{cm}$ kemudian dicuci; $\mathrm{L} 2$ = daging digiling kemudian dicuci . 
0,80. Menurut Huang dan Nip (2001) bahwa dendeng sayat memiliki Aw 0,520,67 dan dendeng giling memiliki Aw 0,620,66 . Tetapi dendeng yang beredar di pasaran pada umumnya memiliki Aw 0,400,50 (Purnomo 1996).

Nilai aktivitas air dendeng bila dimasukkan ke dalam diagram Labuza maka masuk ke dalam daerah II. Pada daerah ini merupakan daerah aktif untuk terjadinya oksidasi, reaksi pencoklatan non enzimatik, aktivitas enzim, hidrolisis dan mulai tumbuhnya kapang. Nilai Aw dendeng hasil penelitian tepat berada di daerah II yang memungkinkan tumbuhnya kapang (Aw lebih dari 0,7). Dengan demikian maka dendeng hasil penelitian ini akan rentan terhadap tumbuhnya kapang.

\section{Indikator Warna}

Derajat kecerahan (“L") dendeng hasil penelitian sangat nyata dipengaruhi oleh faktor pencucian $(\mathrm{P}<0,01)$ sebagaimana disajikan pada Tabel 2 . Rataan nilai L0, L1 dan L2 masing-masing adalah 31,30, 32,48 dan 33,59 dimana L0 tidak berbeda nyata dengan L1 tetapi berbeda nyata dengan L2 dan L1 juga tidak berbeda nyata dengan L2. Berdasarkan nilai rataan tersebut terlihat bahwa pencucian yang dilakukan pada daging

Tabel 2. Indikator warna dendeng daging giling giling (L2) memiliki tingkat kecerahan yang lebih tinggi dari pada L1 dan L0 (tanpa pencucian). Menurut Soekarto (1990) bahwa nilai "L" berkisar dari 0-100 dimana 0 (nol) menunjukkan hitam dan 100 menunjukkan putih. Jadi semakin tinggi nilai "L" maka produk menunjukkan warna yang semakin cerah. Hasil ini menyiratkan bahwa pencucian mungkin telah mampu menghilangkan beberapa komponen yang menyebabkan warna daging atau dendeng menjadi lebih gelap, misalnya Fe pada darah. Meskipun, dengan metode ini tidak menunjukkan adanya pengaruh pencucian terhadap komponen larut air pada daging (Suharyanto et al., 2008), komponen darah akan larut bersama proses pencucian. Fe berperan dalam pembentukan warna baik warna kecoklatan (dalam keadaan teroksidasi) maupun warna kemerahan (dalam keadaan tereduksi). Hilangnya Fe darah turut berperan dalam menurunkan warna kecoklatan dendeng karena keberadaan Fe memungkinkan untuk teroksidasi ketika terjadi pemanasan saat pengeringan.

Selain hal di atas, diduga juga bahwa dengan pengeringan oven pada suhu $80^{\circ} \mathrm{C}$ belum mendegradasi protein, terutamanya mioglobin sehingga Fe yang

\begin{tabular}{|c|c|c|c|c|c|}
\hline \multirow{2}{*}{ Notasi Warna } & \multirow{2}{*}{ Jenis daging } & \multicolumn{3}{|c|}{ Leaching } & \multirow{2}{*}{ Rataan } \\
\hline & & L0 & L1 & L2 & \\
\hline \multirow{4}{*}{$\begin{array}{l}\text { "L" } \\
\text { (kecerahan) }\end{array}$} & Kuda (DK) & $31,05 \pm 0,03$ & $32,33 \pm 0,03$ & $33,08 \pm 0,04$ & $\mathbf{3 2 , 1 5} \pm 0,03$ \\
\hline & Domba (DD) & $32,26 \pm 0,04$ & $32,32 \pm 0,03$ & $32,53 \pm 0,04$ & $32,37 \pm 0,04$ \\
\hline & Sapi (DS) & $30,60 \pm 0,03$ & $32,79 \pm 0,03$ & $35,15 \pm 0,03$ & $32,85 \pm 0,03$ \\
\hline & Rataan & $31,30 \pm 0,03^{a}$ & $32,48 \pm 0,03$ ab & $33,59 \pm 0,04^{b}$ & $32,46 \pm 0,03$ \\
\hline \multirow{4}{*}{$\begin{array}{l}\text { "a" } \\
\text { (kemerahan) }\end{array}$} & Kuda (DK) & $12,92 \pm 0,04$ & $11,91 \pm 0,04$ & $13,11 \pm 0,04$ & $12,65 \pm 0,04$ \\
\hline & Domba (DD) & $12,10 \pm 0,05$ & $11,18 \pm 0,03$ & $10,46 \pm 0,04$ & $11,25 \pm 0,04$ \\
\hline & Sapi (DS) & $11,40 \pm 0,03$ & $11,93+0,03$ & $10,08 \pm 0,04$ & $\mathbf{1 1}, 14 \pm 0,03$ \\
\hline & Rataan & $12,14 \pm 0,04$ & $11,67 \pm 0,03$ & $11,22+0,04$ & $11,68 \pm 0,04$ \\
\hline \multirow{4}{*}{$\begin{array}{l}\text { "b" } \\
\text { (kekuningan) }\end{array}$} & Kuda (DK) & $3,72 \pm 0,05$ & $4,01 \pm 0,04$ & $5,52+0,05$ & $4,42+0,05$ \\
\hline & Domba (DD) & $3,94 \pm 0,04$ & $4,51 \pm 0,05$ & $5,96+0,05$ & $4,80 \pm 0,05$ \\
\hline & Sapi (DS) & $2,89 \pm 0,04$ & $4,69 \pm 0,04$ & $7,36 \pm 0,04$ & $4,98+0,04$ \\
\hline & Rataan & $3,51 \pm 0,04^{a}$ & $4,40+0,04^{a}$ & $6,28 \pm 0,05^{\mathrm{b}}$ & $4,73+0,05$ \\
\hline
\end{tabular}

Keterangan: Angka yang dikuti superskrip berbeda pada baris atau kolom yang sama menunjukkan perbedaan nyata $(\mathrm{P}<0,01)$. L0 = tanpa pencucian; $\mathrm{L} 1=$ daging dipotong berukuran $1,5 \times 1,5 \mathrm{X}$ 1,5 cm kemudian dicuci; L2 = daging digiling kemudian dicuci. 
terikat pada mioglobin belum terlepas. Hasil penelitian Sorensen et al. (2007) menunjukkan bahwa pemanasan pada suhu $120^{\circ} \mathrm{C}$ baru menunjukkan pengaruh nyata pada pelepasan $\mathrm{Fe}$ daging. Terlepasnya Fe akan mempengaruhi perkembangan warna daging pada tahap selanjutnya. Hal ini sejalan dengan Konieczny et al. (2007) yang menyatakan bahwa warna objektif produk Jerky dipengaruhi oleh perlakuan panas. Youssef et al. (2001) menyatakan bahwa dengan pemanasan Charqui maka telah merubah status $\mathrm{Fe}$ dari tereduksi $\left(\mathrm{Fe}^{2+}\right)$ menjadi teroksidasi $\left(\mathrm{Fe}^{3+}\right)$ dan ini sejalan dengan Behrends (2004) yang menyebutkan bahwa perlakuan panas ini dapat meningkatkan konversi status pigmen warna daging dari oksimioglobin menjadi metmioglobin.

Hasil penelitian ini juga menunjukkan bahwa jenis daging tidak mempengaruhi nilai " $L$ " dendeng. Rataan nilai " $L$ " untuk dendeng daging kuda, domba dan sapi masing-masing adalah $32,15,32,37$ dan 32,85. Sedangkan rataan umum nilai "L" dendeng ini adalah 32,46. Nilai ini masih berada dalam kisaran ratarata nilai " $L$ " dendeng yang beredar di pasar, yaitu antara 23,15-36,02 (Nuraini 1996) dan masih lebih tinggi dari hasil penelitian Nuraini (1996) yaitu 28,41. Perbedaan ini mungkin disebabkan oleh jenis daging, metode pembuatan dan komposisi bahan yang digunakan berbedabeda. Meskipun demikian secara umum dendeng yang ada memiliki nilai " $L$ " yang lebih dekat pada nilai 0 (nol) yang berwarna hitam dari pada nilai 100 yang berwarna putih.

Derajat kemerahan dendeng ditunjukkan oleh nilai Hunter "a" yang semakin positif. Nilai yang semakin negatif menunjukkan warna hijau. Semua faktor baik pencucian, jenis daging maupun interaksinya tidak berpengaruh terhadap derajat kemerahan dendeng $(\mathrm{P}>0,05)$ sebagaimana disajikan pada Tabel 2 .
Rataan nilai "a" secara umum adalah 11,68. Bila ditinjau pada faktor pencucian, rataan untuk L0, L1 dan L2 masing-masing adalah $12,14,11,67$ dan 11,22 dan berdasarkan jenis daging maka untuk dendeng daging kuda, domba dan sapi masing-masing adalah 12,65, 11,25, dan 11,14. Hasil ini masih lebih tinggi dari pada hasil penelitian Nuraini (1996) baik pada dendeng yang dibuat dilaboratorium maupun yang beredar di pasar memiliki nilai "a" berkisar antara 0,26-5,50.

Tingginya nilai "a" pada dendeng penelitian ini dibandingkan dengan dendeng lainnya menunjukkan bahwa dendeng ini memiliki derajat warna yang lebih merah. Perbedaan ini diduga karena adanya perbedaan bahan-bahan yang digunakan, proses pengeringan, dan metode pembuatannya. Pembuatan dendeng pada penelitian ini curing dilakukan lebih dahulu baru dicampur dengan bumbu sehingga fiksasi pigmen merah daging terbentuk tanpa adanya gangguan bumbu-bumbu. Derajat kemerahan ini juga dipengaruhi oleh status oksidasi-reduksi ion Fe. Bila dalam ion Fe dalam kondisi tereduksi $\left(\mathrm{Fe}^{2+}\right)$ maka terbentuk oksimioglobin dimana daging berwarna merah cerah. Sebaliknya bila Fe dalam keadaan teroksidasi $\left(\mathrm{Fe}^{3+}\right)$ maka terbentuk metmioglobin yang menghasilkan daging berwarna coklat.

Selain itu, keberadaan nitrit berpengaruh pada fiksasi warna merah daging. Dendeng yang dibuat melalui curing dengan nitrit maka menghasilkan warna yang lebih merah. Mekanisme ini terjadi bila nitrit diubah menjadi oksida nitrat (NO) yang akan berperan dalam mereduksi metmioglobin (coklat) menjadi mioglobin oksida nitrat yang menghasilkan produk berwarna merah. Bila terjadi pemanasan dan denaturasi protein maka akan terbentuk nitrosilhemokromagen yang menyebabkan produk berwarna pink (Aberle et al., 2001). 
Derajat kemerahan dendeng juga dipengaruhi oleh reaksi pencoklatan non enzimatis. Kehadiran gula pereduksi dan protein yang dipicu oleh panas akan menghasilkan reaksi pencoklatan non enzimatis (reaksi maillard). Salah satu hasil akhir reaksi ini adalah adanya produk yang berwarna coklat. Selain itu, selama proses pengeringan terjadi juga pemanasan. Selama pemanasan terjadi denaturasi mioglobin sehingga gugus heme terlepas dari globin. Heme yang terlepas ini sensitif terhadap oksidasi sehingga dengan adanya pemanasan terbentuk warna coklat karena pembentukan pigmen teroksidasi (Nuraini 1996).

Hasil penelitian ini menunjukkan bahwa pencucian berpengaruh nyata terhadap nilai hunter " $b$ " (derajat kekuningan) sebagaimana disajikan pada Tabel 2. Rataan nilai " $b$ " pada L0, L1 dan L2 masing-masing adalah 3,51, 4,40, dan 6,28 dimana L0 dan L1 tidak berbeda nyata tetapi keduanya ini berbeda nyata dengan L2. Nilai " $b$ " antara 0 sampai +70 menunjukkan warna kuning dan antara -70 sampai 0 menunjukkan warna biru. Hasil ini menunjukkan bahwa pencucian pada daging ukuran $1,5 \times 1,5 \times 1,5$ memiliki derajat kekuningan dendeng paling tinggi. Hal ini mungkin karena pencucian pada ukuran daging yang lebih besar dapat mempertahankan Fe darah yang lebih banyak dari pada pada ukuran daging lumat (giling). Kehadiran $\mathrm{Fe}$ dapat menyebabkan dendeng berwarna coklat maupun merah. Hal ini sejalan dengan nilai "L" di atas, dimana pencucian meningkatkan nilai "L" yang berarti semakin mengarah pada warna yang kecerah-cerahan. Hasil penelitian ini juga menunjukkan bahwa jenis daging tidak berpengaruh terhadap nilai " $b$ " dendeng $(P>0,05)$. Rataan nilai " $b$ " untuk dendeng daging kuda, domba, dan sapi masingmasing adalah 4,42, 4,80 dan 4,98. Hasil ini sejalan dengan nilai "L" yang tidak dipengaruhi oleh jenis daging. Sedangkan rataan umum nilai " $b$ " dendeng adalah 4,73 (Tabel 2).

Menurut Nuraini (1996) bahwa tingkat kekuningan ini mungkin berkaitan juga dengan status reaksi pencoklatan non enzimatis yang terjadi. Pada tahap awal reaksi, terjadi reaksi kondensasi antara gugus amino bebas dengan gugus karbonil pada gula pereduksi membentuk glikosilamin yang tidak menghasilkan warna. Pada tahap kedua terjadi pemecahan produk antara (intermediate) menghasilkan senyawa yang berwarna kuning tua. Sedangkan pada tahap ketiga adalah tahap degradasi strecker yaitu terjadinya pemecahan asam amino bebas menjadi aldehida dan N-heterosiklik serta menghasilkan senyawa yang berwarna coklat gelap atau coklat merah. Proses reaksi pencoklatan non enzimatis pada dendeng ini diduga sampai pada tahan kedua yang menghasilkan warna kekuningan.

\section{KESIMPULAN}

Metoda pencucian daging cacah berukuran 1,5 X 1,5 X 1,5 cm dan digiling dengan sekali cuci dapat meningkatkan derajat kecerahan dendeng daging tetapi tidak menurunkan nilai aktivitas air (Aw). Perlu dilakukan penelitian lebih lanjut dengan mengkombinasikan frekuensi pencucian dan kominusi daging.

\section{DAFTAR PUSTAKA}

Aberle ED, JC Forrest, DE Gerrard, EW Mills, HB Hendrick, MD Judge, RA Merkel. 2001. Principles of Meat Science. Edisi ke-4. Kendall/Hunt Puiblishing Co., Dubuque-Iowa. 354 halaman. 
Behrends JM. 2004. Metmyoglobin Reducing Ability and Visual Characteristics of Nine Selected Bovine Muscles. Disertation. Office of Graduate Studies, Texas A\&M University.

Huang TC \& WK Nip. 2001. Intermediatemoisture Meat and Dehydrated Meat. In: Meat Science and Applications. YH Hui, WK Nip, RW Rogers, and OA Young (Eds). Marcel Dekker, New York-Basel. Pp 403-442.

Jin SK, IS Kim, YJ Choi and HS Yang. 2009. Effect of Number of Washes and $\mathrm{pH}$ Adjustment on Characteristics of Surimi-like Materials from Prok Leg Muscle. Asian-Australian Jounal of Animal Science 22 (4): 584-590.

Jin SK, IS Kim, YJ Choi, GB Park and HS Yang. 2008. Quality Characteristics of Breast Chicken Surimi as Affected by Water Washing Time and $\mathrm{pH}$ Adjustment. Asian-Australian Jounal of Animal Science 21 (3): 449-455.

Jin SK, IS Kim, SJ Kim, KJ Jeong, YJ Choi and SJ Hur. 2007. Effect of Muscle Type and Washing Times on Physicochemical Characteristics and Qualities of Surimi. Journal of Food Engineering 81: 618-623.

Konieczny P, J Stangierski, J Kijowski. 2007. Physical and Chemical Characteristics and Acceptability of Home Style Beef Jerky. Meat Science 76: 253-257.

Mega O. 2006a. Beberapa Karakteristik Fisiko-kimia Nukimi Kuda dan Sapi pada Beberapa Frekuensi Pencucian. Jurnal Pengembangan Peternakan Tropis 31 (1): 15-20.

Mega O. 2006b. Stabilitas Emulsi, Susut Masak dan Karakteristik Organoleptik Pasta Nikumi Kuda dan Sapi. Jurnal Sain Peternakan Indonesia 1 (2): 39-44.

Nowsad AA, WF Huang, S Kanoh and E Niwat. 2000. Washing and
Cryoprotectant Effects on Frozen Storage of Spent Hen Surimi. Poultry Science. 79: 913-920.

Nuraini H. 1996. Pengaruh Sendawa (Kalium Nitrat) dan Asam Askorbat terhadap Residu Nitrit dan Pembentukan N-nitrosamin pada Dendeng. Tesis. Program Pascasarjana IPB, Bogor.

Purnomo H. 1997. Studi Tentang Stabilitas Protein Daging Kering dan Dendeng selama Penyimpanan. Laporan Penelitian. FP-Unibraw Press, Malang. 45 halaman.

Salguero JF, R Gomez, MA Carmona. 1994. Water Activity of Spanish Intermedite-moisture Meat Products. Meat Science 38: 342-346.

Suharyanto, R Priyanto, E Gurnardi. 2008. Sifat fisiko-Kimia Dendeng Daging Giling Terkait Cara Pencucian (Leaching) dan Jenis Daging yang Berbeda. Media Peternakan 31 (2): 99106.

Suryaningsih L. 2006. Pengaruh Jenis Daging, Penambahan Antidenaturan dan Natrium Tripolifosfat pada Nikumi terhadap Karakteristik Produk Daging Olahan. Disertasi. Sekolah Pascasarjana IPB, Bogor.

Sørensen AD, H Sørensen, I Søndergaard, K Bukhave. 2007. Non-haem Iron Availability from Pork Meat: Impact of Heat Treatments and Meat Protein Dose. Meat Science 76: 29-37.

Toyoda K, I Kimura, T Fujita, SF Noguchi, and CM Lee. 1992. The Surimi Manufacturing Process. In: Surimi Technology. TC Lanier, CM Lee (Eds). Mercel Dekker, New YorkBasel-Hong Kong.

Youssef EY, CER Garcia, M Shimokamaki. 2001. Effect of Salt on Color and Warmed Over Flavor in Charqui Meat Processing. Brazilian Archives of Biology and Technology 46: 595-600. 